\title{
The structural, relational and cognitive dimensions of social capital on innovation and technology in interorganizational and intraorganizational settings
}

\author{
Leandro R. C. Bonfim ${ }^{\mathrm{a} *}$, Andréa P. Segatto ${ }^{\mathrm{b}}$, and Adriana R. W. Takahashi \\ a,b,c Programa de Pós-Graduação em Administração, Universidade Federal do Paraná, \\ Curitiba, Brazil
}

a,b,c Av. Pref. Lothario Meissner, 632, 2º andar - Jardim Botânico. CEP: 80210-170. Curitiba, Paraná, Brazil.

* a Corresponding author, E-mail: 1rcbonfim@ufpr.br, Ph.D. student in Management at Federal University of Paraná (PPGADM/UFPR). ORCID: 0000-0003-0323-7911

b E-mail: aps@ufpr.br, Associate Professor at Graduate School of Management at Federal University of Paraná (PPGADM/UFPR). ORCID: 0000-0002-8903-9256

${ }^{c}$ E-mail: adrianarwt @terra.com.br, Full Professor at Graduate School of Management at Federal University of Paraná (PPGADM/UFPR). ORCID: 0000-0002-4738-5273

\begin{abstract}
In this article, we intend to understand how structural, relational, and cognitive dimensions of social capital influence innovation outcomes on interorganizational and intraorganizational networks. For achieving this aim, we adopt meta-synthesis research design with nine selected qualitative case studies. We identified through our analysis the patterns of causal relationships among the variables presented on the case studies. The antecedents of social capital dimensions, the influence of the dimensions on reducing barrier or impediments for innovation and on the enhancement of enablers or facilitators of innovation outcomes, and the direct effects of social capital dimensions on innovation compose the resulting framework. We found a balanced relation among the dimensions on interorganizational settings, with a prevalence of the relational dimension. Regarding interorganizational networks, we perceived a reduced role of structural dimension and the absence of the influence of social capital dimension of reducing barriers or impediments for innovation.
\end{abstract}

Keywords: social capital dimensions; social embeddedness; innovation; technology; metasynthesis. 


\section{Introduction}

Innovation and technology development are a longstanding matter for concern among organizational scholars, since innovative organizations usually leads the race for competitive advantage (Sirmon et al. 2011). However, despite the lack for a unanimous explanation of how, where, when they occur, and who are the responsible for innovation and technology within and beyond organizational boundaries, a consistent stream of research have been investigating the impact of social embeddedness of individuals, organizations, and networks, on innovation performance (Powell, Koput and Smith-Doerr 1996; Tsai and Ghoshal 1998; Ruef 2002; Vasudeva, Zaheer and Hernandez 2013).

In this sense, beyond traditionally discussed public policies and research and development (R\&D) investments (Becker and Dietz 2004; Bozeman and Link 2015), networks of relationships have been considered sources of knowledge, information, and resources, which, in turn, are necessary conditions for innovation (Powell 1998; Ahuja 2000; Whittington, OwenSmith and Powell 2009). Thus, social capital theorists emerged in the field, considering that knowledge and resources embedded in networks are no longer individual, being, then, a network resource available to be mobilized and turned into economic gains by their members (Nahapiet and Ghoshal 1998; Lin 1999).

Based on previous traditional studies on social embeddedness (Bourdieu 1985; Granovetter 1985), there was an effort for understanding which network configuration and structure would be optimal for achieving innovation and technology development, especially adopting social network analysis (SNA) methods (e.g. Powell et al. 2005). Later, scholars were concerned with the benefits and drawbacks of engaging in relationships that goes beyond formal and contractual linkages, considering stronger, such as friendship and kinship, in innovation outcomes in interorganizational and intraorganizational settings (Adler and Kwon 2002; Kilduff and Brass 2010). These different perspectives on social capital are consolidated in the literature as structural and relational embeddedness (Granovetter 1992; Moran 2005). Nahapiet and Ghoshal (1998) proposed another dimension of embeddedness considering the shared representations and interpretations among network members, the cognitive dimension.

Thus, the aim of this article is to understand how the structural, relational, and cognitive dimensions of social capital presented on Nahapiet and Ghoshal's (1998) framework influence innovation and technology development in interorganizational and intraorganizational contexts. For achieving this goal, we relied on a meta-synthesis of qualitative case studies (Hoon 2013). Considering that previous literature traditionally investigates such relationship and causal effects by means of quantitative studies (e.g. Tsai and Ghoshal 1998; Landry, Amara and Lamari 2002; Mouw 2006), we argue that an analytical generalization originated from a metasynthesis would be beneficial for the comprehension of the phenomenon of interest, since we are relying on insights gathered from in-depth investigations.

We contribute for both innovation and technology development and social capital literature by proposing an integrated framework composed by antecedents of social capital and the role of social dimensions on reducing barriers or impediments, enhancing enablers or facilitators, and directly affecting innovation outcomes. In this sense, organizations may rely on our findings in order to develop optimal conditions for the improvement of the likelihood of gathering innovation and technology and development outcomes from both interorganizational and intraorganizational networks.

The structure of this article is the following. We start presenting a theoretical background on social capital, its perspectives, and the framework of social capital dimensions we adopted in the analysis of the papers (Nahapiet and Ghoshal 1998). Then, we present previous literature regarding the influence of social capital dimensions on innovation and technology studies. The 
third topic discuss the meta-synthesis research design (Hoon 2013) and the methodological path we took in order to achieve the synthesis we proposed. The fourth topic presents the results of case-level analysis of each case study article and the main findings from cross-case level synthesis. Finally, in the last section we present the discussion, conclusions, limitations and possibilities for future studies.

\section{Theoretical background}

\subsection{Social capital: structural, relational, and cognitive embeddedness}

The study of social relations is the ground for sociological studies since its beginning through Durkheimian and Marxist approaches to social theory (Portes 1998; Breiger 2004). However, only after Mark Granovetter seminal works regarding social embeddedness that the structure of social relations gained much more attention. The author's theory of the strength of the weak ties (Granovetter 1973), along with his proposition of the influence of social embeddedness over economic action (Granovetter 1985) are considered the foundation of the current social networks theory, being, however, fundamental for the development of the social capital perspective (Moran 2005).

Contemporary to Granovetter's contribution to social network theory is Pierre Bourdieu's work that coined the term "social capital" as we know nowadays (Bourdieu 1985). For him, the economic capital, which is directly convertible into monetary gains, is not the only form of capital (i.e., accumulated labour). He asserts that there are two alternative means to access economic benefits: cultural and social capital. Contrary to naturalist explanations given by humanistic traditions, the cultural capital refers to the knowledge (education) and cultural background that may lead a person or a class to succeed in detriment of others (Bourdieu 1985). On the other hand, the Bourdieusian conception of social capital considers it as the accumulated actual or potential resources accessed through the membership in a durable or institutionalized social group, that is, stable network of connections, considering it as a collective-owned capital (Bourdieu 1985). It is noteworthy that the resources are collective-owned, but the rewards of accessing and mobilizing the social capital is for an individual unity (Coleman 1988; Lin 1999).

Another dominant perspective that emerged in the studies of social capital was the communitarian perspective, funded by Robert Putnam (2000). It is distinguishable of previous approaches by considering social capital as a collective aggregate of resources, norms and reciprocity, which, embedded in dense networks, forms a sense of civic virtue in direction of economic development (Woolcock 1998; Putnam 2000; Fukuyama 2001). A commonality between these approaches is the acknowledgement that social capital may be either internal or external, independent of the level of analysis (individual, a small group, or even entire nations), also called bridging and bonding social capital (Putnam 2000). While bonding social capital lies on strong ties among individuals embedded in dense forms of networks, weak ties in sparse and loosed networks are the source of bridging social capital.

Regarding bonding and bridging kinds of social capital, the search for an ideal type of network structure is a long-standing matter of discussion in organizational studies. Two opposite main streams of research emerged from this duality. The first argues that closed and dense networks where individuals have strong ties are more likely to develop higher levels of trust, sharing more knowledge and increasing organizational performance (Coleman 1988; Krackhardt 1992). The second argues that sparse networks where structural holes are present are more likely to guarantee access to non-redundant information and knowledge, leading to increasing organizational performance (Granovetter 1973; Burt 1992). However, it is relevant to argument that the most effective configuration of network structure is context-dependent. Rowley, Behrens, and Krackhardt (2000) found that the former is desirable in mature and stable industries, where the exploitation of knowledge is determinant of organizational performance, 
while the latter is appropriate in dynamic and knowledge intensive contexts, where the exploration of knowledge leads to better performance.

In organizational studies, two main areas of interest on social capital developed recently. The first is concerned to the development of social capital on the intraorganizational level (Tsai and Ghoshal 1998; Tsai 2000; Ahearne, Lam and Kraus 2014), that is, within organizational boundaries. In this sense, social capital was found to be a relevant in explaining strategic alignment (Karahanna and Preston 2013), investors' assessments of CEOs changes (Tian, Haleblian and Rajagopalan 2011), and improvement of employees performance (Ben-Hador 2016). The second main area is concerning the development of interorganizational social capital (Inkpen and Tsang 2005; Sorenson and Rogan 2014), that is, outside organizational boundaries. Recent findings account to social capital the improvement in organizational and alliance performance (Gulati, Lavie and Madhavan 2011; Malik 2012), knowledge transfer and innovation (Filieri et al. 2014; Ivančič, Podmenik and Hafner 2014; Davis 2016), and internationalization (Presutti, Boari and Fratocchi 2016).

It is noteworthy that despite previous focus on the structural configuration of networks in terms of positional advantage, prestige, and access to resources, power and information (Adler and Kwon 2002; Moran 2005; Kwon and Adler 2014), Granovetter's theory of embeddedness states that the relational aspect of social capital is as relevant as the structural (Granovetter 1992). In this sense, scholars might take into account not only the quantity, but also the quality of ties (Uzzi 1997; Moran 2005). Building upon this distinction between structural and relational aspects and upon the Bourdieusian perspective on social capital, Nahapiet and Ghoshal (1998) proposed an analytical framework considering the social capital as a multifaceted and multidimensional concept. For them, social capital is comprised of the overall pattern of impersonal ties in a network (structural dimension), the personal and emotional attachments of actors embedded in a network (relational dimension), and the representations and meanings that are shared by the authors in a network (cognitive dimension).

Thus, traditional social network analysis techniques are used to measure and evaluate the structural dimension of networks. Variables such as density, centrality, cohesion, and structural holes are most commonly adopted for representing network ties, configuration, and appropriability of social capital structural dimension (Borgatti, Jones and Everett 1998; Nahapiet and Ghoshal 1998). For assessing the relational dimension, network shared trust, norms, obligations and identification are the most common variables, as for measuring cognitive dimension, shared codes and language, and shared narratives are the variables proposed by Nahapiet and Ghoshal (1998).

\subsection{Social capital dimensions and innovation: current understandings}

Among several particular fields of organizational studies, innovation and technology research is interested in the social capital as an explanatory theory as well (Bozeman 2000; Landry et al. 2002). Thus, how social capital dimensions may influence the development of innovations and technology? The answer resides in the strict relation between knowledge, resources, and innovation outcomes (Tsai and Ghoshal 1998; Alguezaui and Filieri 2010; Maurer, Bartsch and Ebers 2011).

First, looking into the structural dimension, previous literature considers factors such as knowledge access and sharing, information flow, resources exchanges and complementarities as drivers for innovation in interorganizational settings in both sparse and dense configurations (Ahuja 2000; Alguezaui and Filieri 2010). In his influential work regarding structural dimension of social capital influence on innovation, Ahuja (2000) found that direct ties, indirect ties, and structural holes play different roles in the acquisition of novel knowledge, resources, and diverse information in order to achieve innovation outcomes. Another recent study found 
that an optimal network structure presents a cohesive core, which allows intensive knowledge sharing, but not disconnected with peripheral connections, where is located possible nonredundant knowledge (Gubbins and Dooley 2014). This finding confirm a reconciliation between the perspectives of network cohesion and sparsity proposed by Ronald Burt (2001).

In what concerns to relational and cognitive dimensions, Hammarfjord and Roxenhall (2017) found that shared values and expectations allied to commitment are drivers of innovation in strategic innovation networks. Trust originated from strong ties is recognized as a necessary condition for relevant knowledge exchange (Levin et al. 2016). On the cognitive aspect, shared languages, narratives, vision, and common understandings are predictors of innovation through knowledge transfer, sharing, and creation in interorganizational networks (Nambisan and Sawhney 2011; Tomlinson 2012).

Regarding internal social capital, Tsai and Ghoshal (1998) showed that structural, relational, and cognitive social capital are predictors of resource exchange and combination, which, in turn, leads to product innovation. However, taking into account knowledge transfer as mediator of innovation, more recent findings (Maurer et al. 2011) only found significant relationship between tie strength and knowledge transfer, while trust and number of ties showed no significant relationships. Such contradictions are indicators that the relationship between social capital and innovation still deserves further investigations. Thus, in the next section we will present the methodological procedures adopted in order to construct a meta-synthesis of the relationship between social capital dimensions and innovation in technological contexts.

\section{Methodological procedures}

In order to achieve the aims of this research, we relied on the meta-synthesis method applied to management studies (Hoon 2013). Being the meta-synthesis an "exploratory inductive research design to synthesize primary qualitative case studies for the purpose of making contributions beyond those achieved in the original studies" (Hoon 2013:523), our study intends to refine social capital theory regarding innovation and technology fields by providing an analytical generalization from in-depth and substantive contributions generated from qualitative case studies (Merriam 2009; Yin 2013). As noted by Merriam (2009), this method, alike metaanalysis of quantitative studies, relies on the description and interpretation of data from third parties rather than from original data, being the only realistic way to conduct an investigation considering multiple contexts. The meta-synthesis, in particular, is an alternative for recent calls for the connection of results of isolated case studies to produce more generalized knowledge (Best 2015).

For ensuring rigor and reliability of our meta-synthesis, we followed the protocol established by Hoon (2013). According to her procedures, the meta-synthesis is comprised of eight steps: framing the research question; location relevant research; defining inclusion and exclusion criteria; extracting and coding data; analyzing on a case-specific level; analyzing on an acrossstudy level; building theory from meta-synthesis; and discussing. In Table 1, we summarize the detailed steps, their analytical goals, procedures and outcomes.

-Table 1 goes about here-

One of the critical steps of the investigation is the location of relevant research related to our research question. In this step it is worthwhile to notice that given our critical realist approach to meta-synthesis, we presuppose thematic and methodologic homogeneity (Point, Fendt and Jonsen 2016). Thus, considering our interest was to gather research investigating social capital 
dimensions, we performed a search on Thompson-ISI Web of Knowledge, SCOPUS, and EBSCO-Business Source Complete adopting the boolean search string "social capital" AND "innovati*" AND "technolog*" AND "case stud*". Unlike Hoon (2013), we decided to add the "case stud*" search string by considering that among the large extent of previous research on social capital, most of them have a quantitative nature (e.g. Tsai and Ghoshal 1998; Levin et al. 2016; Hammarfjord and Roxenhall 2017). The search returned a sum of 46 non-repeated studies published from 2003 to 2016 in peer-reviewed journals. We also added two more studies (Camps and Marques 2014; Ehlen et al. 2014) found to be relevant to our research question gathered from a previous search string.

In the next step, we created five inclusion and exclusion criteria in order to filter only studies with potential to help answering our research question (Hoon 2013). In Table 2, we describe each criteria and the rationales behind of them along with the motives of exclusion of each paper. In this stage, we decided that if the paper did not attend one of the criteria we would not evaluate in the next ones. The first criterion was that the study should from a business-related field. Eight out of 48 was from other fields. As second criteria we defined that the paper should present what we called "adequate social capital approach", that is, the paper should explicitly adopt the multidimensional view of social capital as proposed by Nahapiet and Ghoshal (1998). 26 of the 40 remaining papers did not attend the criterion. The third criterion defined that the papers should be related to innovation and technology field. Three out of fourteen remaining papers were excluded. As the fourth criterion, we defined that the studies should be qualitative case studies, being excluded illustrative case examples, quantitative studies, and mixed methods studies. In this step, we did not exclude any study, remaining eleven case studies for the next assessment.

Table 2 goes about here-

The fifth and last criterion was the most subjective one. As proposed by Hoon (2013), the quality of the papers should be assessed. In this sense, after exhaustive reading, we evaluated methodological rigor according to established standards for case studies (Eisenhardt 1991; Merriam 2009; Yin 2013), empirical evidence-based results, and relevant theoretical contribution of each of the eleven studies. We excluded two papers due to quality issues, remaining a final sample of nine case studies included in the meta-synthesis for case-specific analysis and cross-case analysis. In the Table 3, we describe the papers we considered and included in our investigation.

-Table 3 goes about here-

After the selection, exclusion, and inclusion of case studies to our final sample, the fourth step of the meta-synthesis was extracting and coding data from original studies. As we are relying on Hoon's (2013) research design, we adopted the coding and extracting form proposed by her. However, given the specificity of our research question, we decided to pretest the form with two randomly assigned studies of our sample. After the pretest, we added and excluded some items for creating a final form that was more suitable to our research question. We present the final ten items' form that we adopted for tabulating the nine selected case studies in the Table 4. In the quality assessment section (item \#10), we decided to evaluate the studies by grading 
them from $\mathrm{A}+$ (excellent quality) to $\mathrm{D}$ (discardable) in order to increase the reliability of our synthesis.

Table 4 goes about here

Since new insights from meta-studies emerge from analysis of relationships (Point et al. 2016), for analyzing case-specific level (step \#6), we performed an inductive causal network analysis (Miles and Huberman 1994). We looked for emerging variables, patterns and relationships that could emerge in each case analysis, coding them according to reported insights of original researchers. Whenever we found a significant relationship in case-specific, we listed it signaling if the causal relationship was negative or positive (e.g., tie strength [relational dimension] (+) $\rightarrow$ overembeddedness [impediment]).

After analyzing each case separately, we maintained their central metaphors or concepts in order to compare them in a cross-study level in order to reach a final synthesis (Point et al. 2016). In this step of the meta-synthesis (\#7), the patterns of the variables that emerged from combining and comparing case studies are presented and accessed in Table 5, enhancing the validity of the constructs and relationships proposed (Hoon 2013). After verifying the variables and their ratings, we created a meta-causal network, where we were able to identify social capital dimensions' (intraorganizational and interorganizational) variables, its antecedents, the facilitating and impeding factors to innovation, and the direct effects of social capital dimensions on innovation outcomes.

Table 5 goes about here

\section{Analysis and synthesis}

\subsection{Case level-analysis}

In this section, we analyze each case separately in order to consider their contextual and environmental idiosyncrasies (Hoon 2013; Point et al. 2016). Al-Tabbaa and Ankrah (2016) investigated how social capital dimensions functioned as facilitator of knowledge transfer in the case of Faraday Partnerships, in the United Kingdom. The authors investigated five University-Industry partnerships engineered by Faraday agency in two stages, preformation and post-formation. They found that social capital dimensions have distinct roles before and after the establishment of relationships in interorganizational settings. In preformation stage, the presence of intermediaries or brokers and predefined objectives (Faraday rules) fostered the creation of social capital. In this sense, shared obligations and expectations in the relational dimension, and shared codes and narratives and mutual understanding in the cognitive dimension, were fundamental for reducing collaboration impediments such as lack of commonality in the background, fear of priority conflicts, and difficulty in recruiting suitable partners.

In the post-formations stage, the structural dimension gained relevance, since social interaction and network ties played a key role by reducing the difficulty to match partners' capabilities. The structural dimension was also relevant for increasing relational and calculative trust (relational dimension), and shared codes and narratives and common understanding (cognitive dimension). The relational dimension in the post-formation stage were relevant for reducing self-interest and competitive opportunistic behavior. On the other hand, the cognitive dimension helped to reduce communication issues due to cross-sector (public-private) differences (Al- 
Tabbaa and Ankrah 2016). By considering the timing of the influence of social capital in the mitigation of impediments for partnerships between universities and industries, we rated this study as A+ regarding relevance to answer our meta-synthesis research question.

Two studies were held within the European Nordic region concerning the University-Industry context. Partanen and his colleagues (2008) investigated the role of social capital in postinnovation stages, innovation assessment, business development, commercialization, and rapid growth, of three technology-based small-and-medium enterprises (SMEs) in Finland. For this research, we focus on the innovation assessment stage, which is closely tied to innovation development through knowledge, innovation, and technology (KIT) networks. The authors found that relational and cognitive dimensions of social capital are relevant for innovation assessment. They argued that strong ties were relevant for joint learning and development, while weak ties were important for rapid and extensive learning of new ideas. Sharing the same codes and language of academics was important for gathering effective communication to share technological development with universities. In this sense, sharing the same codes, languages, values and norms made possible the increasing of relational trust necessary for innovation in knowledge-intensive settings. We also rated this study as $\mathrm{A}+$ for answering our research question, since it brings new insights regarding stage and timing of social capital dimensions and development.

In turn, Steinmo (2015) studied six firms engaged in collaboration alliances with public research organizations (PROs) in Norway. She found that relational and cognitive dimensions of social capital are means to mitigate collaboration challenges between industries and universities on the individual, firm, and alliance levels. In the relational dimension, mutual and close acquaintance, trust and openness, mutual engagement and commitment, effective communication reduced collaboration challenges. The cognitive aspect of social capital found by the author as reducers of collaboration challenges were shared goals and languages, and common understanding. We argue that the structural dimension also had a minor role, since network cohesion and closeness, and the structure of collaboration helped in the reduction of alliances' challenges as well. Given insightful contributions for understanding social capital dimensions and its relationship with innovation on a multilevel perspective, we rated this paper as $\mathrm{A}+$ regarding the potential contribution for answering our meta-synthesis research question.

Masiello, Izzo and Canoro (2015) proposed to investigate what would be the structural, relational and cognitive configuration of social capital that would be effective in the process of knowledge creation, transfer and sharing between SMEs and PROs in five innovation-driven networks in Italy. The authors found that tie strength and network stability (structural dimension) facilitate innovation outcomes due to the faster and symmetrical learning during knowledge transfer process. The informality of the relationship governance, based on trust, reputation, and mutual expectations in constant multilevel personal exchanges were relational factors identified as innovation facilitators. In the cognitive dimension, they found that shared goals and vision, shared language and cultural background, and knowledge base complementarity were fundamental for innovation in the networks, increasing knowledge and information flow and absorptive capacity between the partners.

Another interesting findings regarding the relational dimension presented in the study (Masiello et al. 2015) was that intimacy and emotional commitment, allied with tie strength, led to overembeddedness, inertial trust (non-calculative behavior), power asymmetry and mutual dependence. Two cases in their sample presented such configuration, leading only to incremental innovation. They argued that dyadic relationships have a life cycle in inverted Ushape. In this sense, initial stages of collaboration are highly formalized and less creative and innovative. In the exploration stage, they perceived a higher level of informality, creativity, and innovation. Finally, in the exploitation stage, when revenues and dividends of the relationship 
are collected, they found higher levels of formalization and lesser levels of creativity and innovation. We considered that this study presents a relevant contribution for the field by relating knowledge, social capital and innovation through multiple cases in innovation-driven networks. Thus, we rated it as an A+ paper.

Another study with external focus proposed a framework where knowledge productivity, that is, "the competence of individuals and groups to gradually improve and radically innovate in operating procedures, products and services" (Ehlen et al. 2014:58), would mediate the relationship between social capital dimensions and organizational innovation. It is noteworthy that the authors added a fourth dimension, the action dimension, to Nahapiet and Ghoshal's (1998) framework. However, for analytical generalization purpose, we decided to focus only on structural, relational, and cognitive dimensions in the meta-synthesis. Through a multiple case study, involving six innovation groups engaged in the Healthcare Academy program in the Netherlands, they found that multidisciplinary network configuration and continuous participation (engagement) in the programme (structural dimension) increased knowledge productivity. Concerning relational dimension, the factors that increased knowledge productivity were positive relationships (trust, motivation, appreciation, and sympathy), mutual acquaintance, and collaboration. In the cognitive dimension, the authors found that shared goals and values, common understanding, creativity, and collective subject-matter expertise affected positively the knowledge productivity, and hence, organizational innovation. Overall, the paper introduces interesting insights, but methodological inconsistencies and the lack of empirical support for some arguments led us to rate it as a $\mathrm{B}+$ paper.

The article of Hughes and Perrons (2011) was the only study in our sample that investigated an interorganizational setting in the business-to-business (B2B) private context of the English printing technology. The authors argued that deciding whether keeping an established technology or adopting a disruptive technology leads to divergent options regarding the dimensions of social in the buyer-supplier relationship. In this sense, time and resource constrains are inhibitors of social capital development. Given that tie strength (relational dimension) may lead to blindness of opportunity and relational dependence, the authors found that relying on weak ties and building cooperative norms would be effective for innovation assessment. The authors' insights are relevant, but they do not provide much evidence that could help answering the meta-synthesis research question (overall rating: B-).

Three studies focused on the intraorganizational (internal) aspects of social capital dimensions in industrial settings. Camps and Marques (2014) proposed to investigate whether social capital dimensions would be heterogeneous within organizations, influencing different innovation capabilities. The research setting was one machinery industry from processing food industry in Spain. They identified two groups: high-identification groups (HIG) and medium-identification groups (MIG). HIGs were found in dense network configurations (structural dimension), with strong ties, higher levels of trust and shared values, norms and obligations (relational dimension), and sharing vision of organizational goals, codes, and narratives (cognitive dimension).

On the other hand, MIGs presented sparse network configurations (structural dimension), prevailing weaker ties (relational dimension), lower identification with the organization, weaker trust (relational dimension), and shared vision of organizational goals, values, norms and obligations (cognitive dimension) towards process efficiency and human relations. For both groups, the relational dimension was linked to the following innovation enablers, goal alignment, associability, concern of collective, collective action innovation flow, cooperation, knowledge enhancement, control mechanism, flexibility, a creative environment, and risk taking. The cognitive dimension was attached to goal alignment as innovation enabler (Camps 
and Marques 2014). Given the contribution to the understanding of group heterogeneity in intraorganizational social capital, we rated this study as an A+.

Ozermir and Demirc1 (2012) studied how social capital dimensions influenced radical innovation efforts of an aviation industry in Turkey. They found that structural aspects (tie redundancy) reduced innovation efforts. Tie strength, competence trust, and norm reciprocity were considered positive influence to innovation efforts in the relational dimension of social capital. Regarding cognitive dimension, the authors argued that shared goals and common identity enhanced innovation efforts within the company. And finally, Roman-Castillo and Smida (2013) also studied an aviation industry-related company, but a SME which produces virtual reality simulators in Colombia. The authors found that personal traits of the owners (human capital), such as ethic values, commitment, and relational competence, were fundamental for relational (shared trust) and cognitive (shared values and collective goals) social capital development. Due to the lack of direct observation of the influence of social capital on innovation outcomes in the later, and the lack of novelty in the former, we rated both studies as B-.

\subsection{Cross-studies synthesis}

After analyzing each study individually, the next step is the cross-studies analysis that leads to the meta-synthesis. In this sense, the aim is to find a coherent pattern of relationships among the variables we identified in the selected case studies. The results of the meta-causal network analysis are depicted in the Figure 1. We noticed that every study presented some kind of what we called dimensional relationships, that is, the dimensions are not isolate from each other, showing mutual influence in most of the cases. In the model, we represent it through the intersection among the dimensions in the center of the Figure 1.

We were also able to find social capital dimensions' antecedents. We also argue that it may function fostering innovation directly, or even mediating innovation outcomes through reducing barriers, impediments and inhibitors, or enhancing enablers and facilitators to innovation outcomes. As we described in the case-level analysis, social capital dimensions play different roles depending on the focus of analysis. Thus, we divided the meta-causal model in external (interorganizational) and internal (intraorganizational) social capital.

-Figure 1 goes about here-

In what refers to the interorganizational social capital, we perceived a relative balance among the contributions of each dimension, being relational dimension the most prominent. In the structural dimension, we found that intermediaries and brokers are antecedents of network ties formation. Despite not having a direct effect on innovation outcomes, network ties influence relational and cognitive dimensions. In the relational dimension, they are predictors of how calculative and relational trust are built. Calculative trust emerges from positive expectations of gains based on rational choices, while relational trust are based on positive emotions and appreciation resulting from regular interactions (Al-Tabbaa and Ankrah 2016). Another variable in the structural dimension affecting relational trust is network memory or past ties. In this sense, when a collaboration is based on previous relationships, relational trust is more likely to emerge. Network ties are also expected to produce effects on cognitive dimension of social capital by increasing the likelihood of shared codes and narratives, and of common understanding among the parties. 
Concerning innovation enablers in the structural dimension, we propose that network configuration or structure may increase knowledge productivity (Ehlen et al. 2014). Positional advantage and reputation may facilitate the access to venture capital investments when an alliance needs to implement innovations (Partanen et al. 2008). Regarding the mitigation of innovation impediments, we argue that finding an adequate network configuration or structure helps reducing collaboration challenges and the risk of non-matching capabilities within the network. Cohesion and closeness is another variable responsible for reducing collaboration challenges. However, tie stability may reduce rapid and extensive learning due to the lack of new knowledge acquisition and limited information flow. We also found evidence to propose that having indirect ties, multilevel interactions and exchanges between collaboration partners, and tie stability may have direct positive effects on innovation outcomes (Masiello et al. 2015).

In the relational dimension of social capital in interorganizational networks, we found results that are more complex than in the structural dimension. As antecedents, we propose that the amount of time and resource allocation will increase the mutual commitment and engagement in the collaboration. Furthermore, alliances formed through intermediaries and brokers with predefined objectives are more likely to have shared norms and clear perceptions of mutual obligations and expectations. We also perceived relevant dimensional relationships. Intimacy and emotional commitment and openness to partners are found to increase shared codes and narratives and common understanding in the cognitive dimension. Mutual commitment and engagement are considered factors with potential to increase the extent of network ties in the structural dimension. We also perceived intradimensional relationships, as tie strength increases shared norms among partners, but may also lead to relational dependence. Another issue that might be noticed is that throughout longstanding collaboration, partners may lose the notion of effective gains, keeping relationships that are no longer beneficial to the parties, what is called an inertial trust (Masiello et al. 2015).

We also identified variables in the relational dimension that leads to innovation enablers or reduces the barriers for innovation. The innovation enabler of knowledge productivity increases in the presence of relational trust, with positive relationships among the parties, when there is the perception of mutual engagement and commitment, close acquaintance, and mutual collaboration and expectation. Another enabler, joint learning and development, occurs when the relationships are composed of strong ties. Regarding barriers, collaboration challenges may be mitigated through effective communication, mutual engagement and commitment, close acquaintance, openness to partners, and shared norms. Opportunistic behaviors are avoided when the collaboration have relational and calculative trust, and openness to partners. Relational trust, along with shared obligations and expectations, helps reducing fear of priority conflicts and partner suitability challenges.

In this dimension, we argue that there is a limit for engagement. Excess of intimacy and emotional commitment and tie strength may lead the collaboration to overembeddedness and blindness of opportunity. This process may be reversed through power symmetry and mutual dependency (Masiello et al. 2015). Furthermore, innovation outcomes are more likely to be directly and positively affected when the network are formed by strong ties with relational trust, having informal governance structures with prevalence of power symmetry and mutual dependency, where collaboration and expectations are balanced among all partners.

In the lower half of Figure 1, we represent the relational model of intraorganizational social capital. We noticed the presence of almost the same elements contained in the model for interorganizational networks (antecedents, enablers, and direct effects on innovation outcomes), except for barriers, impediments or inhibitors. Additionally, we found that the dimensions of social capital are not as balanced as we perceived on the interorganizational setting. For instance, we identified only one variable of the structural dimension with negative 
direct effect in innovation outcomes, tie redundancy. In this sense, for internal networks the diversity of ties may be more effective for gathering new knowledge and information (Ozermir and Demirc1 2012). Concerning the cognitive dimension, only shared goals, vision, and values is relevant for providing a favorable environment for innovation. Personal commitment from employees, ethic values, and higher relational competence are predictors of shared goals, vision, and values, that, in turn, increases the chance for getting innovation enablers such as effective control mechanisms, collective action, internal cooperation, concern of collective, risk taking propensity, and goal alignment.

In intraorganizational networks, organizations the relational dimension of social capital is more valuable if compared to structural and cognitive dimensions. Relational trust, which is preceded by personal commitment from employees, ethic values and relational competence, increases the effectiveness of control mechanism, leads to internal cooperation, collective action, and associability as innovation enablers. Another facilitating factors related to relational trust are the development of a creative environment, the better flow of information and elevated risk taking propensity. Mutual commitment and engagement, shared norms, and shared identity are relational variables that may lead to improvement of organizational control mechanisms, collective action, concern of collective, internal cooperation, associability, better information flow and knowledge enhancement, impacting directly on innovation outcomes as well.

Looking into internal social capital, we found an intradimensional relation between tie strength and trust. Strong ties are more likely to lead to competence trust, that is, one partner trust the capacity of others to perform effectively their jobs, while weak ties are more likely to lead to benevolence trust, that is, one partner trust that others will lookout for his welfare (Ozermir and Demirc1 2012; Levin et al. 2016). Regarding observed direct effects, we argue that competence trust, shared norms, shared identity, and tie strength are positively related to innovation outcomes in intraorganizational networks.

\section{Discussion and conclusion}

This article investigated through a meta-synthesis (Hoon 2013) how structural, relational and cognitive dimensions of social capital (Nahapiet and Ghoshal 1998) are related to innovation and technology in organizations. We relied on the assumption that innovation outcomes in organizations and networks goes beyond structural variables (Adler and Kwon 2002; Kwon and Adler 2014), such as density, centrality, cohesion, and centralization. Thus, in-depth case studies may be suitable for understanding the complexity of the relationships among and within organizations, where knowledge, information, and resources are exchanged not only by rational and economic means.

The results of this study permit us to assert that social capital dimensions play different roles according to the level of relationship analyzed. In interorganizational networks, relational aspects are prominent, while structural and cognitive dimensions are relevant, but in lesser extent. On the other hand, on intraorganizational settings, relational social capital is fundamental, with structural and cognitive dimensions playing secondary roles for explaining innovation, contradicting previous findings of Tsai and Ghoshal (1998). They found that all three dimensions presented significant roles in the resource exchange and combination, which in turn, leaded to innovation. However, size and contextual factors might explain such differences, since their results were based on a study of a large multinational, while in our sample, the authors investigated small and medium-sized companies (Ozermir and Demirc1 2012; Roman-Castillo and Smida 2013; Camps and Marques 2014). Concerning relational dimension, while in previous study tie strength were the only relational variable found to lead to innovation (Maurer et al. 2011), we propose through our model that relational trust, shared 
norms, shared identity, and mutual commitment and engagement are also relevant factors explaining innovation, directly or not.

In what concerns to interorganizational networks, our findings are consistent with previous literature (e.g. Ahuja 2000; Nambisan and Sawhney 2011; Levin et al. 2016). Structurally, both weak and strong ties are relevant for gathering innovation in interorganizational alliances. Extensive and stable networks, with fewer "turnover" ratios, are more likely to develop trust, knowledge productivity, and cognitive alignment among partners. In this sense, we agree with Levin and Cross (2004) when they argue that trust and trustworthiness are essential for knowledge creation and transfer, since we found that networks with positive innovation results presented informal governance structures. Thus, since we found that network memory constituted by previous known ties as a source of relational trust, we argue that it is an interesting avenue for future studies for those interested in the relation between social capital dimensions and innovation outcomes.

In the relational dimension, we found that mutual commitment and engagement is a notably relevant variable for explaining innovation outcomes in interorganizational networks, what is consistent with recent arguments in innovation and technology studies (Hammarfjord and Roxenhall 2017). We argue that time and resource allocation from all partners engaged in the collaboration are source for network commitment and engagement. It is noticeable that engaged and committed organizations are important for network expansion, since bringing new ties to the alliance is favorable for generating new non-redundant knowledge and information. Consequently, the more committed to network the organizations are, the more likely they are to achieve innovation outcomes in technological contexts.

Our findings regarding cognitive dimension of social capital are aligned with Nahapiet and Ghoshal's (1998) propositions. Even in cross-sector or cross-industry collaborations, developing shared languages and narratives and a common understanding is important for achieving innovation outcomes. Relational aspects of social capital, especially relational trust, shared norms, and tie strength, are important sources of these cognitive variables (Al-Tabbaa and Ankrah 2016). In this dimension, shared goals, vision, and values, is the only factor we identified as relevant in both network contexts, interorganizational and intraorganizational.

We also had an unexpected outcome from out meta-synthesis. During our investigation, we were able to address a subject of interest of a growing body of scholars interested in the study of networks, the dark side of social capital (Labianca and Brass 2006; Kwon and Adler 2014; Portes 2014). In this matter, we found evidence to agree with Molina-Morales and his colleagues (2011) when they assert that too much relational trust may have a negative effect on innovation outcomes. Despite being fundamental for knowledge creation and transfer among organizations, in excess it may lead to overembeddedness (Uzzi 1997; Masiello et al. 2015). As consequence, organizations may become, borrowing the expression from Gargiulo and Benassi (2000), trapped in their own net. In this sense, inertial trust, relational dependence, blindness of opportunities and power and resource asymmetry (Gulati and Sytch 2007; Hughes and Perrons 2011) may become pitfalls for organizations to gather novel knowledge and information in order to innovate.

Our framework contributes to extant literature by showing that social capital dimensions are relevant source of innovation both in intraorganizational and interorganizational networks. We propose that this influence is threefold. First, it is a source of innovation outcomes by enhancing or improving innovation enablers and facilitators. Second, it helps organizations to innovate by mitigating or reducing barriers, impediments, or inhibitors that block innovation in interorganizational networks. Third, we argue that social capital dimensions may also be direct sources of innovation for organizations, even under influence of idiosyncratic contexts, 
cultures, and institutions (Sahin, Nijkamp and Stough 2009). Additionally, we also presented variables that may be antecedents of social capital, being, then, an initial path for further investigations on social capital development.

This study, however, presents some limitations. Despite our efforts to locate all relevant case studies about social capital and innovation, it is likely that some relevant cases were not located, since we focused only on three databases. Another limitation, inherent to the method we adopted for conducting this research, is that we relied on another researcher's insights and interpretation of data, being susceptible to their bias. Still, adopting qualitative case studies insights for getting to an analytical generalization reduces the deepness, richness, and contextual dependence of original authors' findings. We also consider a limitation the fact that eight out of nine case studies selected were located in the European continent. Even considering that out sample was composed by distinct industries and contexts, case studies from other regions in the globe could present different results if compared to European reality depicted in this study. Finally, we argue that the quantitative character of its original constructs may disguise the relevance of the structural dimension of social capital, since they were evaluated by means of qualitative data sources.

This investigation opens up diverse possibilities for future studies. Our framework could be analyzed in new empirical situations, considering collaborations on distinct contexts (publicprivate, B2B, etc.). We recommend researchers to explore further the role of social capital dimensions in the impediments or barrier for innovation. Researches in this matter could foster collaboration among isolate organizations (lone wolves) which despite having available resources and knowledge, are not motivated to be embedded in innovation-driven networks (Kwon and Adler 2014). Another possibility would be the investigation of the extent of the limits of the bright side of social capital before it turns into dark side. A possible contribution would be the avoidance of innovation inhibitors such as overembededdness, inertial trust, and asymmetric relationships.

\section{References}

Adler, Paul S and Seok-Woo Kwon. 2002. "Social Capital: Prospects for a New Concept." Academy of Management Review 27(1):17-40.

Ahearne, Michael, Son K Lam and Florian Kraus. 2014. "Performance Impact of Middle Managers' Adaptive Strategy Implementation: The Role of Social Capital." Strategic Management Journal 35(1):68-87.

Ahuja, Gautam. 2000. "Collaboration Networks, Structural Holes, and Innovation: A Longitudinal Study." Administrative Science Quarterly 45(3):425-455.

Al-Tabbaa, Omar and Samuel Ankrah. 2016. "Social Capital to Facilitate 'Engineered' University-Industry Collaboration for Technology Transfer: A Dynamic Perspective." Technological Forecasting and Social Change 104:1-15.

Alguezaui, Salma and Raffaele Filieri. 2010. "Investigating the Role of Social Capital in Innovation: Sparse Versus Dense Network." Journal of Knowledge Management 14(6):891909.

Becker, Wolfgang and Jurgen Dietz. 2004. "R\&D Cooperation and Innovation Activities of Firms-Evidence for the German Manufacturing Industry." Research Policy 33(2):209-223. 
Ben-Hador, Batia. 2016. "How Intra-Organizational Social Capital Influences Employee Performance." Journal of Management Development 35(9):1119-1133.

Best, Joel. 2015. "Beyond Case Studies: Expanding the Constructionist Framework for Social Problems Research." Qualitative Sociology Review 11(2):18-33.

Borgatti, Stephen P, Candace Jones and Martin G Everett. 1998. "Network Measures of Social Capital." Connections 21(2):27-36.

Bourdieu, Pierre. 1985. "The Forms of Capital." in Handbook of Theory and Research for the Sociology of Education, edited by J. G. Richardson. New York: Greenwood.

Bozeman, Barry. 2000. "Technology Transfer and Public Policy." Research Policy 29(4):627655.

Bozeman, Barry and Albert N Link. 2015. "Toward an Assessment of Impacts from Us Technology and Innovation Policies." Science and Public Policy 42(3):369-376.

Breiger, Ronald L. 2004. "The Analysis of Social Networks." Pp. 505-526 in Handbook of Data Analysis, edited by M. A. Hardy and A. Bryman. London, UK: Sage Publications.

Burt, Ronald S. 1992. "Structural Holes: The Social Structure of Competition." Pp. 57-93 in Network and Organizations: Structure, Form and Action, edited by R. G. Eccles and N. Nohria. Boston, MA: Harvard Business School Press.

Burt, Ronald S. 2001. "Structural Holes Versus Network Closure as Social Capital." Pp. 31-56 in Social Capital: Theory and Research, edited by N. Lin, K. S. Cook and R. S. Burt. New Brunswick, NJ: Transaction.

Camps, Susanna and Pilar Marques. 2014. "Exploring How Social Capital Facilitates Innovation: The Role of Innovation Enablers." Technological Forecasting and Social Change 88:325-348.

Coleman, James S. 1988. "Social Capital in the Creation of Human Capital." American Journal of Sociology 94(Supplement):S95-S120.

Davis, Jason P. 2016. "The Group Dynamics of Interorganizational Relationships Collaborating with Multiple Partners in Innovation Ecosystems." Administrative Science Quarterly 61(4):621-661.

Ehlen, Corry, Marcel van der Klink, Uta Roentgen, et al. 2014. "Knowledge Productivity for Sustainable Innovation: Social Capital as Hrd Target." European Journal of Training \& Development 38(1/2):54-74.

Eisenhardt, Kathleen M. 1991. "Better Stories and Better Constructs: The Case for Rigor and Comparative Logic." Academy of Management Review 16(3):620-627.

Filieri, Raffaele, Regina C McNally, Michele O'Dwyer, et al. 2014. "Structural Social Capital Evolution and Knowledge Transfer: Evidence from an Irish Pharmaceutical Network." Industrial Marketing Management 43(3):429-440. 
Fukuyama, Francis. 2001. "Social Capital, Civil Society and Development." Third World Quarterly 22(1):7-20.

Gargiulo, Martin and Mario Benassi. 2000. "Trapped in Your Own Net? Network Cohesion, Structural Holes, and the Adaptation of Social Capital." Organization Science 11(2):183-196.

Granovetter, Mark S. 1973. "The Strength of Weak Ties." American Journal of Sociology 78(6):1360-1380.

Granovetter, Mark S. 1985. "Economic Action and Social Structure: The Problem of Embeddedness." American Journal of Sociology 91(3):481-510.

Granovetter, Mark S. 1992. "Economic Institutions as Social Constructions: A Framework for Analysis." Acta sociologica 35(1):3-11.

Gubbins, Claire and Lawrence Dooley. 2014. "Exploring Social Network Dynamics Driving Knowledge Management for Innovation." Journal of Management Inquiry 23(2):162-185.

Gulati, Ranjay and Maxim Sytch. 2007. "Dependence Asymmetry and Joint Dependence in Interorganizational Relationships: Effects of Embeddedness on a Manufacturer's Performance in Procurement Relationships." Administrative Science Quarterly 52(1):32-69.

Gulati, Ranjay, Dovev Lavie and Ravindranath Ravi Madhavan. 2011. "How Do Networks Matter? The Performance Effects of Interorganizational Networks." Research in Organizational Behavior 31:207-224.

Hammarfjord, Magnus O and Tommy Roxenhall. 2017. "The Relationships between Network Commitment, Antecedents, and Innovation in Strategic Innovation Networks." International Journal of Innovation Management 21(6):17500371-175003736.

Hoon, Christina. 2013. "Meta-Synthesis of Qualitative Case Studies an Approach to Theory Building." Organizational Research Methods 16(4):522-556.

Hughes, Mathew and Robert K. Perrons. 2011. "Shaping and Re-Shaping Social Capital in Buyer-Supplier Relationships." Journal of Business Research 64(2):164-171.

Inkpen, Andrew C and Eric W K Tsang. 2005. "Social Capital, Networks, and Knowledge Transfer." Academy of Management Review 30(1):146-165.

Ivančič, Angela, Darka Podmenik and Ana Hafner. 2014. "Independent Inventors, Social Capital, and Knowledge Transfer - the Case of Slovenia." Innovation: The European Journal of Social Science Research 27(3):238-253.

Karahanna, Elena and David S Preston. 2013. "The Effect of Social Capital of the Relationship between the Cio and Top Management Team on Firm Performance." Journal of Management Information Systems 30(1):15-56.

Kilduff, Martin and Daniel J Brass. 2010. "Organizational Social Network Research: Core Ideas and Key Debates." Academy of Management Annals 4(1):317-357. 
Krackhardt, David. 1992. "The Strength of Strong Ties: The Importance of Philos in Organizations." Pp. 216-239 in Networks and Organizations: Structure, Form, and Action, edited by N. Nohria and R. G. Eccles. Boston, MA: Harvard Business School Press.

Kwon, Seok-Woo and Paul S Adler. 2014. "Social Capital: Maturation of a Field of Research." Academy of Management Review 39(4):412-422.

Labianca, Giuseppe and Daniel J Brass. 2006. "Exploring the Social Ledger: Negative Relationships and Negative Asymmetry in Social Networks in Organizations." Academy of Management Review 31(3):596-614.

Landry, Réjean, Nabil Amara and Moktar Lamari. 2002. "Does Social Capital Determine Innovation? To What Extent?". Technological Forecasting and Social Change 69(7):681-701.

Levin, Daniel Z and Rob Cross. 2004. "The Strength of Weak Ties You Can Trust: The Mediating Role of Trust in Effective Knowledge Transfer." Management Science 50(11):14771490 .

Levin, Daniel Z, Jorge Walter, Melissa M Appleyard, et al. 2016. "Relational Enhancement: How the Relational Dimension of Social Capital Unlocks the Value of Network-Bridging Ties." Group \& Organization Management 41(4):415-457.

Lin, Nan. 1999. "Social Networks and Status Attainment." Annual Review of Sociology 25:467487.

Malik, Tariq. 2012. "Disparate Association between Alliance Social Capital and the Global Pharmaceutical Firm's Performance." International Business Review 21(6):1017-1028.

Masiello, Barbara, Francesco Izzo and Cristina Canoro. 2015. "The Structural, Relational and Cognitive Configuration of Innovation Networks between Smes and Public Research Organisations." International Small Business Journal 33(2):169-193.

Maurer, Indre, Vera Bartsch and Mark Ebers. 2011. "The Value of Intra-Organizational Social Capital: How It Fosters Knowledge Transfer, Innovation Performance, and Growth." Organization Studies 32(2):157-185.

Merriam, Sharan B. 2009. Qualitative Research: A Guide to Design and Implementation. San Francisco, CA: Jossey-Bass.

Miles, Matthew B and A Michael Huberman. 1994. Qualitative Data Analysis: An Expanded Sourcebook. Thousand Oaks, CA: Sage.

Molina-Morales, F Xavier, M Teresa Martínez-Fernández and Vanina Jasmine Torlò. 2011. "The Dark Side of Trust: The Benefits, Costs and Optimal Levels of Trust for Innovation Performance." Long Range Planning 44(2):118-133.

Moran, Peter. 2005. "Structural Vs. Relational Embeddedness: Social Capital and Managerial Performance." Strategic Management Journal 26(12):1129-1151.

Mouw, Ted. 2006. "Estimating the Causal Effect of Social Capital: A Review of Recent Research." Annual Review of Sociology 32:79-102. 
Nahapiet, Janine and Sumantra Ghoshal. 1998. "Social Capital, Intellectual Capital, and the Organizational Advantage." Academy of Management Review 23(2):242-266.

Nambisan, Satish and Mohanbir Sawhney. 2011. "Orchestration Processes in Network-Centric Innovation: Evidence from the Field." Academy of Management Perspectives 25(3):40-57.

Ozermir, Aytul Ayşe and Ahmet Emre Demırc1. 2012. "Impact of Social Capital on Radical Innovation Efforts of the Organizations: A Case in the Aviation Industry." Ege Akademik Bakış 12(1):53-66.

Partanen, Jukka, Kristian Möller, Mika Westerlund, et al. 2008. "Social Capital in the Growth of Science-and-Technology-Based Smes." Industrial Marketing Management 37(5):513-522.

Point, Sébastien, Jacqueline Fendt and Karsten Jonsen. 2016. "Qualitative Inquiry in Management: Methodological Dilemmas and Concerns in Meta-Analysis." European Management Review In press:1-20.

Portes, Alejandro. 1998. "Social Capital: Its Origins and Applications in Modern Sociology." Annual Review of Sociology 24(1):24.

Portes, Alejandro. 2014. "Downsides of Social Capital." Proceedings of the National Academy of Sciences 111(52):18407-18408.

Powell, Walter W, Kenneth W Koput and Laurel Smith-Doerr. 1996. "Interorganizational Collaboration and the Locus of Innovation: Networks of Learning in Biotechnology." Administrative Science Quarterly 41(1):116-145.

Powell, Walter W. 1998. "Learning from Collaboration: Knowledge and Networks in the Biotechnology and Pharmaceutical Industries." California Management Review 40(3):228-240.

Powell, Walter W, Douglas R White, Kenneth W Koput, et al. 2005. "Network Dynamics and Field Evolution: The Growth of Interorganizational Collaboration in the Life Sciences 1." American Journal of Sociology 110(4):1132-1205.

Presutti, Manuela, Cristina Boari and Luciano Fratocchi. 2016. "The Evolution of InterOrganisational Social Capital with Foreign Customers: Its Direct and Interactive Effects on Smes’ Foreign Performance." Journal of World Business 51(5):760-773.

Putnam, Robert D. 2000. Bowling Alone: The Collapse and Revival of American Community. New York: Simon and Schuster.

Roman-Castillo, Ruth E and Ali Smida. 2013. "El Rol De Las Variables De Nivel Individual En La Formación De Capital Social Organizativo. El Caso De Una Microempresa De Base Tecnológica." Management International 17(2):164-183.

Rowley, Tim, Dean Behrens and David Krackhardt. 2000. "Redundant Governance Structures: An Analysis of Structural and Relational Embeddedness in the Steel and Semiconductor Industries." Strategic Management Journal 21(3):369-386.

Ruef, Martin. 2002. "Strong Ties, Weak Ties and Islands: Structural and Cultural Predictors of Organizational Innovation." Industrial and Corporate Change 11(3):427-449. 
Sahin, Mediha, Peter Nijkamp and Roger R Stough. 2009. "Socio-Cultural Drivers of Innovation." Innovation: The European Journal of Social Science Research 22(3):247-249.

Sirmon, David G, Michael A Hitt, R Duane Ireland, et al. 2011. "Resource Orchestration to Create Competitive Advantage Breadth, Depth, and Life Cycle Effects." Journal of Management 37(5):1390-1412.

Sorenson, Olav and Michelle Rogan. 2014. "(When) Do Organizations Have Social Capital?". Annual Review of Sociology 40:261-280.

Steinmo, Marianne. 2015. "Collaboration for Innovation: A Case Study on How Social Capital Mitigates Collaborative Challenges in University-Industry Research Alliances." Industry and Innovation 22(7):597-624.

Tian, Jie Jenny, Jerayr John Haleblian and Nandini Rajagopalan. 2011. "The Effects of Board Human and Social Capital on Investor Reactions to New Ceo Selection." Strategic Management Journal 32(7):731-747.

Tomlinson, Philip R. 2012. "Industry Institutions, Social Capital, and Firm Participation in Industrial Development." Industrial and Corporate Change 21(1):1-29.

Tsai, Wenpin and Sumantra Ghoshal. 1998. "Social Capital and Value Creation: The Role of Intrafirm Networks." Academy of Management Journal 41(4):464-476.

Tsai, Wenpin. 2000. "Social Capital, Strategic Relatedness and the Formation of Intraorganizational Linkages." Strategic Management Journal 21(9):925-939.

Uzzi, Brian. 1997. "Social Structure and Competition in Interfirm Networks: The Paradox of Embeddedness." Administrative Science Quarterly 42(1):35-67.

Vasudeva, Gurneeta, Akbar Zaheer and Exequiel Hernandez. 2013. "The Embeddedness of Networks: Institutions, Structural Holes, and Innovativeness in the Fuel Cell Industry." Organization Science 24(3):645-663.

Whittington, Kjersten Bunker, Jason Owen-Smith and Walter W Powell. 2009. "Networks, Propinquity, and Innovation in Knowledge-Intensive Industries." Administrative Science Quarterly 54(1).

Woolcock, Michael. 1998. "Social Capital and Economic Development: Toward a Theoretical Synthesis and Policy Framework." Theory and Society 27(2):151-208.

Yin, Robert K. 2013. Case Study Research: Design and Methods. Thousand Oaks, CA: Sage. 
Table 1. Meta-synthesis research protocol

\begin{tabular}{|c|c|c|c|}
\hline $\begin{array}{l}\text { Steps in meta- } \\
\text { synthesis }\end{array}$ & Analytical goal & $\begin{array}{l}\text { Strategy/analytical } \\
\text { procedure used }\end{array}$ & $\begin{array}{l}\text { Outcome to generate a } \\
\text { theoretical } \\
\text { contribution }\end{array}$ \\
\hline $\begin{array}{l}\text { Framing the research } \\
\text { question }\end{array}$ & $\begin{array}{l}\text { Stating a clear research } \\
\text { question regarding the } \\
\text { relationship between the } \\
\text { constructs social capital } \\
\text { dimensions } \\
\text { innovation and } \\
\text { technology. }\end{array}$ & A priori specification. & $\begin{array}{l}\text { How are social capital } \\
\text { dimensions (structural, } \\
\text { relational and cognitive) } \\
\text { related to innovation and } \\
\text { technology in } \\
\text { organizations? }\end{array}$ \\
\hline $\begin{array}{ll}\text { Locating } & \text { relevant } \\
\text { research } & \end{array}$ & $\begin{array}{l}\text { Identifying the adequate } \\
\text { keywords to find relevant } \\
\text { research (case studies) } \\
\text { that helps to answer the } \\
\text { research question stated } \\
\text { in the first step. }\end{array}$ & 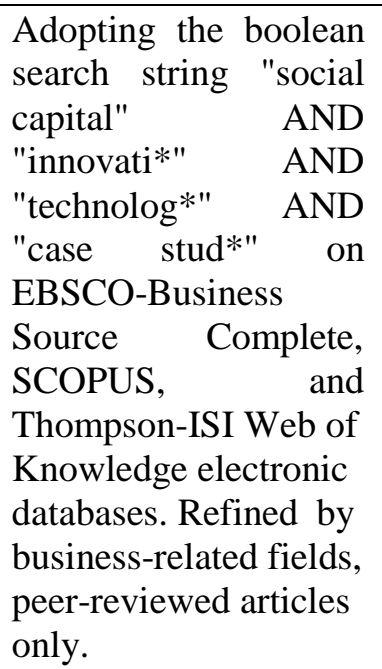 & $\begin{array}{l}\text { The search string in the } \\
\text { mentioned electronic } \\
\text { databases returned a } \\
\text { sum of } 46 \text { not repeated } \\
\text { case studies to be } \\
\text { examined according to } \\
\text { the established criteria } \\
\text { by the researcher. Two } \\
\text { additional case studies } \\
\text { were included in the fist } \\
\text { stage due to their } \\
\text { relevance for answering } \\
\text { the research question. }\end{array}$ \\
\hline $\begin{array}{l}\text { Creating } \\
\text { inclusion/exclusion } \\
\text { criteria }\end{array}$ & $\begin{array}{l}\text { Defining criteria for } \\
\text { inclusion/exclusion that } \\
\text { may be adherent to the } \\
\text { proposed research } \\
\text { question, to the adopted } \\
\text { approach to social } \\
\text { capital, and to the type of } \\
\text { study demanded for the } \\
\text { meta-synthesis (case } \\
\text { studies). }\end{array}$ & $\begin{array}{l}\text { Developing an } \\
\text { inclusion/exclusion } \\
\text { criteria list; discussing } \\
\text { clear exclusion } \\
\text { criteria. Clear criteria } \\
\text { for inclusion/exclusion } \\
\text { may ensure reliability } \\
\text { and validity of the } \\
\text { methodological } \\
\text { procedures adopted. }\end{array}$ & $\begin{array}{l}\text { After extensive } \\
\text { examination according } \\
\text { to the criteria previously } \\
\text { established, } 11 \text { out of } 48 \\
\text { case studies were } \\
\text { included in the final } \\
\text { assessment (criteria \#5). } \\
\text { The final sample of the } \\
\text { meta-synthesis was } \\
\text { composed by } 9 \text { selected } \\
\text { studies. The criteria } \\
\text { adopted were: 1, } \\
\text { business related field; } 2, \\
\text { adequate social capital } \\
\text { approach; } \\
\text { innovation/technology } \\
\text { related; 4, qualitative } \\
\text { case-study; } 5 \text {, quality of } \\
\text { the study regarding } \\
\text { methodological } \\
\text { description, empirical } \\
\text { evidence-based } \\
\text { affirmations, and } \\
\text { relevant theoretical } \\
\text { contribution. }\end{array}$ \\
\hline
\end{tabular}




\begin{tabular}{|c|c|c|c|}
\hline $\begin{array}{l}\text { Extracting } \\
\text { coding data }\end{array}$ & $\begin{array}{l}\text { Carefully reading the full } \\
\text { text of each study. } \\
\text { Coding study } \\
\text { characteristics as well as } \\
\text { the proceeded insights of } \\
\text { the primary studies } \\
\text { according to the research } \\
\text { question on social capital } \\
\text { and } \\
\text { innovation/technology. }\end{array}$ & $\begin{array}{l}\text { Adapting Hoon's } \\
\text { coding form to the } \\
\text { research question of } \\
\text { this study. Codes were } \\
\text { added/excluded } \\
\text { according to the } \\
\text { authors judgement } \\
\text { after pretesting the } \\
\text { code list. }\end{array}$ & $\begin{array}{l}\text { Order, code, and } \\
\text { categorize evidence } \\
\text { from each of the case- } \\
\text { studies. }\end{array}$ \\
\hline $\begin{array}{l}\text { Analyzing on a case- } \\
\text { specific level }\end{array}$ & 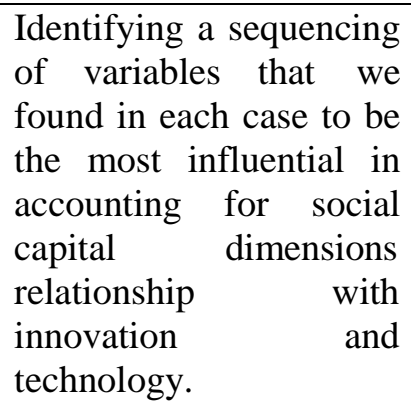 & $\begin{array}{l}\text { Case-specific causal } \\
\text { networks. }\end{array}$ & $\begin{array}{l}\text { Identifying themes, core } \\
\text { concepts, patterns, or } \\
\text { relationships in each } \\
\text { case. }\end{array}$ \\
\hline $\begin{array}{l}\text { Synthesis on a cross- } \\
\text { study level }\end{array}$ & $\begin{array}{l}\text { Merging the case- } \\
\text { specific causal networks } \\
\text { into a meta-causal } \\
\text { network. Accumulating } \\
\text { the sequencing of } \\
\text { variables at a cross-study } \\
\text { level to arrive at a } \\
\text { general pattern among } \\
\text { these variables. }\end{array}$ & $\begin{array}{l}\text { Meta-causal network, } \\
\text { variable ratings. }\end{array}$ & $\begin{array}{l}\text { Identification of a } \\
\text { pattern; social capital } \\
\text { dimensions as central } \\
\text { variable; rating of the } \\
\text { variables to ensure } \\
\text { validity. }\end{array}$ \\
\hline $\begin{array}{l}\text { Building theory from } \\
\text { meta-synthesis }\end{array}$ & $\begin{array}{l}\text { Identifying the relation } \\
\text { between structural, } \\
\text { relational and cognitive } \\
\text { dimensions of social } \\
\text { capital and } \\
\text { innovation/technology } \\
\text { development. }\end{array}$ & $\begin{array}{l}\text { Linking the findings } \\
\text { back to the literature } \\
\text { on social capital. }\end{array}$ & $\begin{array}{l}\text { Identification of patterns } \\
\text { of relations in the studies } \\
\text { in order to build a meta- } \\
\text { causal theory. }\end{array}$ \\
\hline Discussion & $\begin{array}{l}\text { Discussion of the results } \\
\text { of the meta-synthesis } \\
\text { study and potential } \\
\text { limitations. }\end{array}$ & $\begin{array}{l}\text { Discussing } \\
\text { reliability, } \\
\text { validity. }\end{array}$ & $\begin{array}{l}\text { Legitimizing the } \\
\text { validity and reliability of } \\
\text { the procedure and } \\
\text { activities used. }\end{array}$ \\
\hline
\end{tabular}

Adapted from Hoon (2013:529) 
Table 2. Inclusion and exclusion criteria

\begin{tabular}{|c|c|c|}
\hline Criteria & Rationales & Excluded papers \\
\hline $\begin{array}{l}\text { (1) Business-related } \\
\text { field }\end{array}$ & $\begin{array}{l}\text { We used this criterion to narrow the } \\
\text { meta-synthesis only to business- } \\
\text { related field due to our strict interest } \\
\text { of the phenomenon in organizational } \\
\text { settings. }\end{array}$ & $\begin{array}{l}\text { Aula \& Harmaakorpi (2008), public } \\
\text { policy; Exner et al. (2016), public } \\
\text { policy; McMichael \& Shipworth } \\
\text { (2013), public policy; Nielsen } \\
\text { (2003), public policy; Pitkänen } \\
\text { (2016), public policy; Scheffran, } \\
\text { Marmer, \& Sow (2012), } \\
\text { geography/climate; van der Horst } \\
\text { (2011), geography/climate; Vico } \\
\text { (2014), research policy. }\end{array}$ \\
\hline $\begin{array}{l}\text { (2) Adequate social } \\
\text { capital approach }\end{array}$ & $\begin{array}{l}\text { We based our understanding of } \\
\text { social capital and its dimensions } \\
\text { based in the framework proposed by } \\
\text { Nahapiet and Ghoshal (1998). Thus, } \\
\text { we only considered studies that } \\
\text { explicitly considered this approach } \\
\text { to social capital dimension in the } \\
\text { case study analysis. }\end{array}$ & $\begin{array}{l}\text { Adina \& Ramona (2013); Baba \& } \\
\text { Walsh (2010); Banerjee, Yadav, \& } \\
\text { Banerjee (2016); Barbosa, Noronha, } \\
\text { \& Castro (2012); Beckett (2008); } \\
\text { Blomqvist, Hurmelinna, \& Seppänen } \\
\text { (2005); Bocquet \& Mothe (2011); } \\
\text { Borges \& Filion (2013); Cannone, } \\
\text { Pisoni, \& Onetti (2014); Driedonks } \\
\text { et al. (2005); Elola, Valdaliso, \& } \\
\text { Lopez (2013); Gittins, Lang, \& Sass } \\
\text { (2015); Hansson, Husted, \& } \\
\text { Vestergaard (2005); Ivančič, } \\
\text { Podmenik, \& Hafner (2014); Muafi } \\
\text { (2015); Ragin-Skorecka (2016); } \\
\text { Rothschild \& Darr (2005); Rutten \& } \\
\text { Boekema (2007); Silva \& Reis } \\
\text { (2015); Smedlund (2006); Smith } \\
\text { (2009); Smith (2012); Tseng, Wang, } \\
\text { \& Yen (2014); van Burg et al. } \\
\text { (2008); Wang \& Ahmed (2004); } \\
\text { Wilson, Coleman, \& Herron (2008). }\end{array}$ \\
\hline $\begin{array}{l}\text { (3) Innovation and } \\
\text { technology related } \\
\text { field }\end{array}$ & $\begin{array}{l}\text { As our intention was to analyze the } \\
\text { dimensions of social capital in the } \\
\text { innovation and technology field, we } \\
\text { decided to exclude papers addressing } \\
\text { other fields (marketing, education, } \\
\text { finance, etc.). }\end{array}$ & $\begin{array}{l}\text { Bogers \& Sproedt (2012), } \\
\text { education/learning; Makkonen \& } \\
\text { Virtanen (2015), IT platform; Reich } \\
\text { \& Kaarst-Brown (2003), human } \\
\text { resources management. }\end{array}$ \\
\hline $\begin{array}{l}\text { (4) Qualitative case } \\
\text { study }\end{array}$ & $\begin{array}{l}\text { We adopted this criterion because } \\
\text { qualitative case studies makes } \\
\text { possible in-depth understandings } \\
\text { (Merriam 2009) of the relationship } \\
\text { we were intending to investigate. }\end{array}$ & No exclusion. \\
\hline $\begin{array}{l}\text { (5) Quality } \\
\text { assessment (methods, } \\
\text { empirical evidence, } \\
\text { theoretical } \\
\text { contribution) }\end{array}$ & $\begin{array}{l}\text { We checked exhaustively all studies } \\
\text { to ensure that only quality insights } \\
\text { and findings would be included in the } \\
\text { meta-synthesis. We accessed } \\
\text { methodological rigor, empirical } \\
\text { evidence-based findings, and }\end{array}$ & $\begin{array}{l}\text { Tondolo et al. (2015), the paper only } \\
\text { recognizes the dimensions of social } \\
\text { capital, but do not address it } \\
\text { empirically in the case; Valdaliso et } \\
\text { al (2011), we could not identify the } \\
\text { methodological procedures adopted } \\
\text { in the case study. The authors did not }\end{array}$ \\
\hline
\end{tabular}




\begin{tabular}{|l|l|l|}
\hline $\begin{array}{l}\text { theoretical contributions of each } \\
\text { paper. }\end{array}$ & $\begin{array}{l}\text { let clear if the empirical evidence } \\
\text { was based on historical research or } \\
\text { interviews with key actors (as stated } \\
\text { in the abstract only) }\end{array}$ \\
\hline
\end{tabular}

Adapted from Hoon (2013:535). 
Table 3. Final sample of case studies included in the meta-synthesis

\begin{tabular}{|l|l|l|l|}
\hline Authors & Journal & Year & $\begin{array}{l}\text { Impact factor } \\
\text { (JCR/SJR/H)* }\end{array}$ \\
\hline $\begin{array}{l}\text { (Al-Tabbaa and } \\
\text { Ankrah) }\end{array}$ & $\begin{array}{l}\text { Technological Forecasting and Social } \\
\text { Change }\end{array}$ & 2016 & $2.678 / 1.348 / 68$ \\
\hline $\begin{array}{l}\text { (Camps and } \\
\text { Marques) }\end{array}$ & $\begin{array}{l}\text { Technological Forecasting and Social } \\
\text { Change }\end{array}$ & 2014 & $2.678 / 1.348 / 68$ \\
\hline $\begin{array}{l}\text { (Ehlen et al.) } \\
\text { European Journal of Training \& }\end{array}$ & 2014 & NA/0.489/23 \\
\hline $\begin{array}{l}\text { (Hughes and } \\
\text { Perrons) }\end{array}$ & Journal of Business Research & 2011 & $2.129 / 1.682 / 114$ \\
\hline (Masiello et al.) & International Small Business Journal & 2015 & $2.215 / 2.054 / 46$ \\
\hline $\begin{array}{l}\text { (Ozermir and } \\
\text { Demirc1) }\end{array}$ & Ege Akademik Bak1ş & 2012 & None \\
\hline (Partanen et al.) & Industrial Marketing Management & 2008 & $1.930 / 1.413 / 90$ \\
\hline $\begin{array}{l}\text { (Roman-Castillo } \\
\text { and Smida) }\end{array}$ & Management International & 2013 & None \\
\hline (Steinmo) & Industry and Innovation & 2015 & $0.870 / 1.298 / 41$ \\
\hline
\end{tabular}

The authors (2017). *Journals' impact factor are the ratio a journal is cited related to the numbers of papers published by them in a given period. We collected the JCR is the Journal Citation Reports, provided by Thomson Reuters, SJR is the SCImago Journal Rank, provided by SCImago, and the H index provided by SCOPUS. 
Table 4. Coding and extracting form

\begin{tabular}{|c|c|}
\hline Item/question & Content \\
\hline $\begin{array}{l}\text { 1. General details of the } \\
\text { study }\end{array}$ & $\begin{array}{l}\text { Authors; title, journal, volume, issue, pages, and year; and type of } \\
\text { study (empirical or not). }\end{array}$ \\
\hline $\begin{array}{l}\text { 2. What are the authors } \\
\text { trying to achieve? }\end{array}$ & $\begin{array}{l}\text { Broader aim(s) of the study; research question(s); and intended } \\
\text { contributions. }\end{array}$ \\
\hline 3. Theoretical framing & $\begin{array}{l}\text { Conceptual understanding of social capital used; conceptual } \\
\text { understanding of innovation used; and theoretical relationship } \\
\text { between social capital/innovation. }\end{array}$ \\
\hline $\begin{array}{l}\text { 4. Setting/context in which } \\
\text { study was conducted }\end{array}$ & $\begin{array}{l}\text { Country; industry/sector; type of relationship (public-private, } \\
\text { university-industry, B2B, etc.); focus of social capital } \\
\text { (external/internal); type of innovation (radical/incremental, } \\
\text { product/service, etc.); research context (dynamic or not/mature or } \\
\text { nascent); research site selected (type of organization); and research } \\
\text { setting (e.g. three technology based companies). }\end{array}$ \\
\hline 5. Methodology/methods & $\begin{array}{l}\text { Research design; approach (e.g. theory building/theory testing); unity } \\
\text { of analysis; number of cases included; and sampling strategy. }\end{array}$ \\
\hline $\begin{array}{l}\text { 6. Data collection techniques } \\
\text { and sources }\end{array}$ & $\begin{array}{l}\text { Timing and sequencing (e.g. retrospective, real time); data collection } \\
\text { techniques; data sources (transcripts, field notes, archival data); and } \\
\text { amount of data conducted/validity. }\end{array}$ \\
\hline 7. Data analysis approach & Methods of data analysis; and analysis techniques. \\
\hline $\begin{array}{l}\text { 8. What are the proceeded } \\
\text { insights? (verbatim } \\
\text { paraphrased) }\end{array}$ & $\begin{array}{l}\text { Key findings summarized by the original researcher(s) in } \\
\text { abstract/introduction/conclusion sections; events, factors, or patterns } \\
\text { in social capital portrayed by the original author(s); events, factors, } \\
\text { or patterns in innovation/technology portrayed by the original } \\
\text { author(s); and effects of social capital on innovation and technology } \\
\text { as portrayed by the original author(s). }\end{array}$ \\
\hline 9. Discussion & $\begin{array}{l}\text { Discussion of key findings; contribution(s) as stated by the original } \\
\text { researcher(s); limitations as discussed by the authors; and limitations } \\
\text { (e.g. methodological). }\end{array}$ \\
\hline $\begin{array}{l}\text { 10. Overall assessment } \\
\text { (every item were evaluated } \\
\text { as follows: A+: excellent } \\
\text { quality; A-: good quality; } \\
\text { B+: average quality; B-: } \\
\text { below average quality; C: } \\
\text { poor quality; D: discardable) }\end{array}$ & $\begin{array}{l}\text { How relevant is this study to underlying question?; how } \\
\text { reliable/convincing is this study?; missing information/logical } \\
\text { inconsistencies?; further assessment. }\end{array}$ \\
\hline
\end{tabular}

Adapted from Hoon (2013:536-537) 
Table 5. Variables and ratings

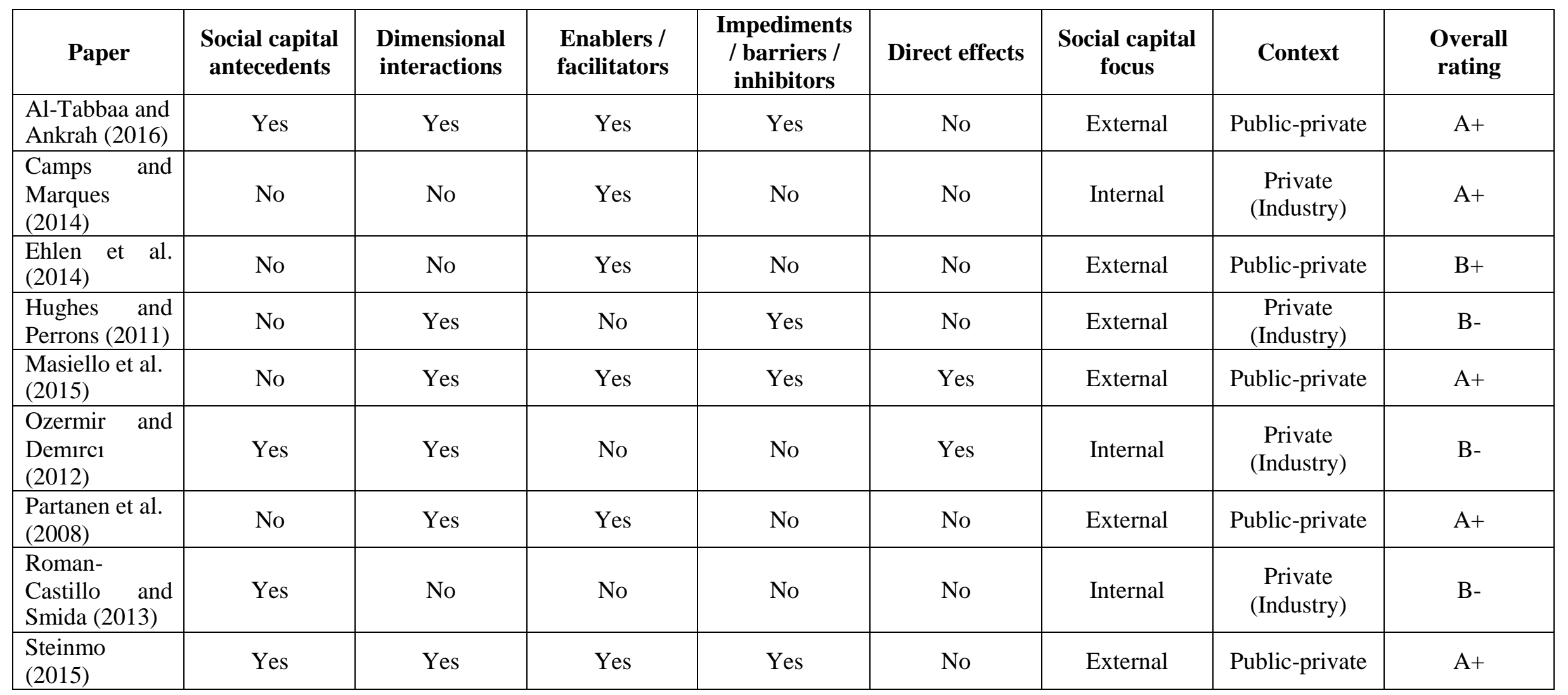

Adapted from Hoon (2013:540-541) 
Figure 1. Meta-causal model of relations of social capital dimensions

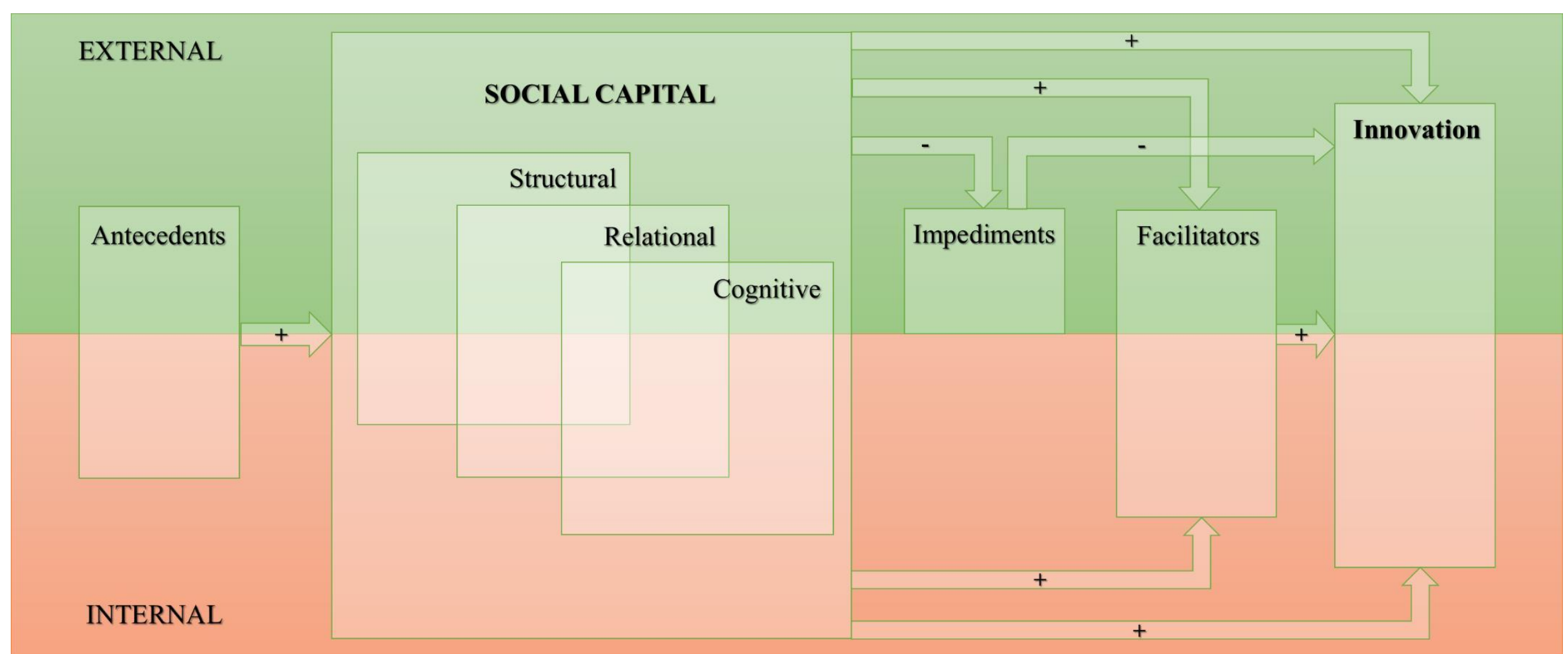

The authors (2017) 